\title{
Improving Students' Scientific Literacy: Learning Studies Using Science Teaching Materials on Circulatory System Materials
}

\author{
*Karimah, A. Wahab Jufri, Agus Ramdani \\ Magister of Science Education Program, Universitas Mataram, Jl. Majapahit No.62, \\ Mataram, Indonesia, 83115. \\ *Corresponding Author e-mail: karimahzain85@gmail.com
}

Received: June 2021; Revised: June 2021; Published: June 2021

\begin{abstract}
Scientific literacy is very important in determining the quality of education in a country. The importance of scientific literacy for students because it can invite students to understand the environment, health, economy and many other problems facing modern society. This study aim to develop an integrated science teaching material with guided inquiry model that appropriate to improve students' scientific literacy. This research is a development research using the Dick \& Carey model. In addition to developing science teaching materials, this research also develops syllabus, lesson plans, and scientific literacy instruments. This research was conducted in one of the NW MTs in West Lombok Regency. The validation of learning products was carried out by three validators, media experts and material experts. Expert validation data analysis was carried out using the Pearson validation formula. The results of the feasibility study of integrated science teaching materials using guided inquiry models obtained an average value of $94 \%$ with very valid criteria. The syllabus got an average score of $87 \%$, lesson plans got an average score of $92 \%$, and the scientific literacy instrument got an average score of $82 \%$. In conclusion, the product of integrated science teaching materials with guided inquiry models is feasible to be implemented in learning process.
\end{abstract}

Keywords: scientific literacy; science teaching materials; guided inquiry; circulatory system

How to Cite: Karimah, K., Jufri, A., \& Ramdani, A. (2021). Improving Students' Scientific Literacy: Learning Studies Using Science Teaching Materials on Circulatory System Materials. Prisma Sains : Jurnal Pengkajian Ilmu dan Pembelajaran Matematika dan IPA IKIP Mataram, 9(1), 57-63. doi:https://doi.org/10.33394/jps.v9i1.3878

https://doi.org/10.33394/j-ps.v9i1.3878

Copyright $\odot$ 2021, Karimah et al This is an open-access article under the CC-BY License.

\section{INTRODUCTION}

The PISA (Program for International Student Assessment) study by the OECD (Organization for Economic Cooperation and Development) is conducted every 3 years in order to obtain continuous information on student achievement to determine the level of quality of Indonesian education in the international sphere (Fakhriyah, et al., 2017; Jufrida, et al., 2019). Based on the results of the PISA study, it proves that on average Indonesian students have low scientific literacy skills compared to the international average which reaches a score of 500 (Toharudin, 2011; Ramdani, et al., 2020). With this achievement, the average scientific ability of Indonesian students has only reached the ability to recognize a number of basic facts, but they have not been able to communicate and relate that ability to various science topics, let alone apply complex and abstract concepts (Hadisaputra, et al., 2019).

Fitriani and Lestari (2014) also stated that the low quality of students' science learning outcomes indicates that the science learning process in Indonesian schools does not train students' scientific literacy. The trend of science learning today is that students learn it as a product, memorize concepts, theories and laws. Therefore, Putra, et al (2016) stated that the low level of scientific literacy of Indonesian students is a strong evidence that science learning in Indonesia still needs to be improved, based on a study of the results of the PISA 
study it can be concluded that what is being taught so far is different from the needs of the students human.

The results of textbook analysis conducted by Adisendjaja (2008) show that there are still many books that only present scientific knowledge ranging from facts, concepts, principles, laws, and theories that only require students to remember knowledge or information. It is the same with research on the content of Biology subject matter that has been carried out (Setiawan, 2019), where the results show that most of the themes presented are more focused on a series of science knowledge content.

Based on the results of observations and interviews with science subject teachers and several students at MTs NW, West Lombok Regency, that science learning is still difficult, uninteresting, and unpleasant because the implementation of learning is still conventional, which is based on monotonous books and is teacher-centered. (teacher oriented). Natural Science (science) is built based on scientific steps through the analysis of facts so that it becomes a concept, law, and arrives at a theory. Therefore, science learning should pay more attention to improving students' scientific literacy skills and critical thinking skills by facilitating learning using learning media in the form of teaching materials developed so that learning processes and outcomes become more meaningful.

One of the teaching materials that can improve students' scientific literacy skills is teaching materials with a guided inquiry learning model. This is in accordance with the results of research by Ramdani, et al., (2020b); Komalasari, et al (2019); Hasanah, et al (2019) stated that science teaching materials that have been developed with the inquiry learning model can improve students' higher-order thinking skills because in its implementation, student activities show an increase in indicators of higher-order thinking skills such as designing, experimenting, and analyzing results. . In addition, the teaching materials developed by Puspitasari, et al (2019) can improve student learning outcomes in terms of knowledge, attitudes, and science process skills. According to Saglam and Sahin, (2017), inquiry-based learning can help teachers teach science so that students have the ability to think critically, produce creative solutions to a problem, and become scientifically literate by following the methods of scientists.

Based on these problems, science learning at MTs NW, West Lombok Regency has not met the demands of the curriculum, namely student-centered learning because the teaching materials used are still in the form of teaching materials that only describe content in terms of knowledge. This study aim to develop integrated science teaching materials with guided inquiry models to improve students' scientific literacy skills on the Circulatory System material.

\section{METHOD}

The development of guided inquiry teaching materials in this study refers to the learning development model of Dick \& Carey (2009). In addition to developing teaching materials, researchers also developed a syllabus, lesson plans, and scientific literacy test instruments. The Dick \& Carey development model consists of 10 stages. This research is limited to the eighth stage, namely designing and conducting formative evaluation. Formative evaluation is carried out with the validation stage or expert test to determine the quality of the teaching materials that have been developed using a validation assessment questionnaire, the assessment is carried out by 3 experienced validators (Nieveen, 1999). The validity assessment uses a Likert scale with gradations as listed in Table 1. The validity scores (NA) of the three validators are averaged to obtain the final validity score of teaching materials.

Table 1. Product Assessment Criteria (Widoyoko, 2012)

\begin{tabular}{cll}
\hline Interval & \multicolumn{1}{c}{ Category } & \multicolumn{1}{c}{ Information } \\
\hline $3.6<\bar{X} \leq 4.00$ & Very valid & Can be used without revision \\
$2.6<\bar{X} \leq 3,5$ & Valid & Usable with minor revisions \\
$1.6<\bar{X} \leq 2.5$ & Not valid & Cannot be used because it needs to be revised \\
$1.0<\bar{X} \leq 1.5$ & Invalid & Can not be used \\
\hline
\end{tabular}




\section{RESULTS AND DISCUSSION}

This study uses the Dick \& Carey model which is focused on the stage of designing and conducting formative evaluation which includes validity testing. The development of guided inquiry integrated science teaching materials first goes through the design and evaluation stages. At the design stage, content analysis, and literature review are appropriate. Many parts are decided in this section, such as the equipment needed, the number of instruments to be developed, the type of instrument selected, the material determined, namely the circulatory system, and who will be involved in this research. In addition, student analysis, task analysis, concept analysis and specification of learning objectives were also carried out.

The main purpose of the design phase is to prepare a prototype device such as test preparation, media selection, and format selection. At this stage the first device design was also produced which included the syllabus, lesson plans (Learning Implementation Plan) and test instruments. Android-based learning media products use an inquiry model. Ariningsih, et al (2014) stated several steps of inquiry learning in general, namely orientation, formulating problems, proposing hypotheses, collecting data, testing hypotheses, and formulating conclusions. These steps aim to emphasize the importance of solving various problems that are displayed in the developed teaching materials. In addition to development in terms of learning activities that are adapted to the syntax of the learning model.

The purpose of this design stage is to design products in the form of guided inquirybased biology learning tools that can improve students' creative thinking skills and learning outcomes. The learning tools produced in this study were in the form of syllabus, lesson plans, LKPD used by educators in teaching the kingdom fungi material as well as creative thinking instruments and learning outcomes used by educators for assessment materials. The main activity carried out in this stage is designing the format of the learning device. The specifications of the devices developed in general are the arrangement of learning tools based on the syntax of the guided inquiry model, indicators of creative thinking skills and indicators of learning outcomes. At each stage, students are directed how to build a creative thinking ability based on the scientific method.

The syllabus is a reference for the preparation of the learning framework for each subject study material. In this research, one type of syllabus has been developed, namely guided inquiry based. In addition, the syllabus is also integrated with scientific literacy indicators. The Learning Implementation Plan (RPP) which is the subject of discussion developed in the RPP is the kingom fungi material, which is implemented in four meetings to evaluate learning using scientific literacy instruments. Science teaching materials are used as a means to help maximize the learning process in the classroom. Teaching materials that are prepared based on the syntax of guided inquiry are also integrated with scientific literacy indicators. The results of developing guided inquiry integrated science teaching materials are presented in Figure 1.

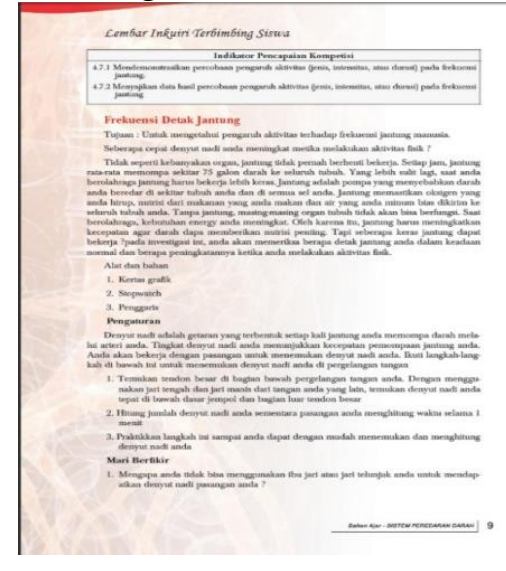

a

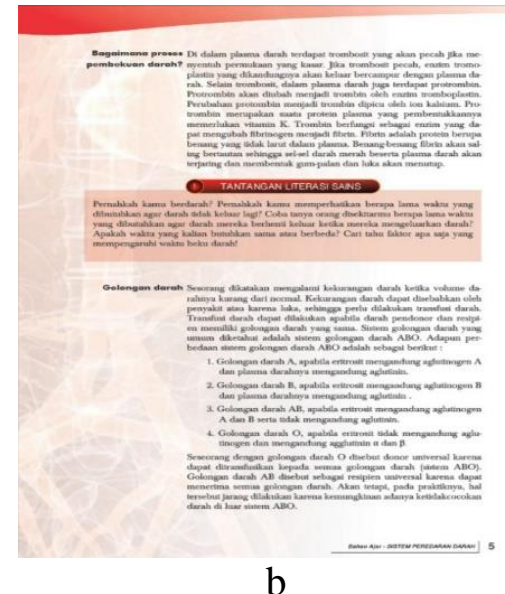

$\mathrm{b}$

Figure 1. Display of Science teaching materials: (a). Guided Inquiry Pages; (b) Material Pages 
The instrument used to measure scientific literacy was 10 multiple choice questions. The multiple-choice questions are developed according to the needs of students and contain scientific literacy indicators complete with assessment rubrics. In the process of teaching materials for integrated science guided inquiry, there are suggestions for improvement from the validator, such as including material aspects. In addition, the images used in guided inquiry integrated science teaching materials must be of high quality to make them appear clearer. The selection of high quality images will make students happy and enthusiastic in learning activities (Suranti, et al., 2020). The guided inquiry integrated science teaching materials produced as initial drafts have gone through a validation test process by three expert validators who review aspects of content, presentation and learning activities. The results are presented in Figure 2.

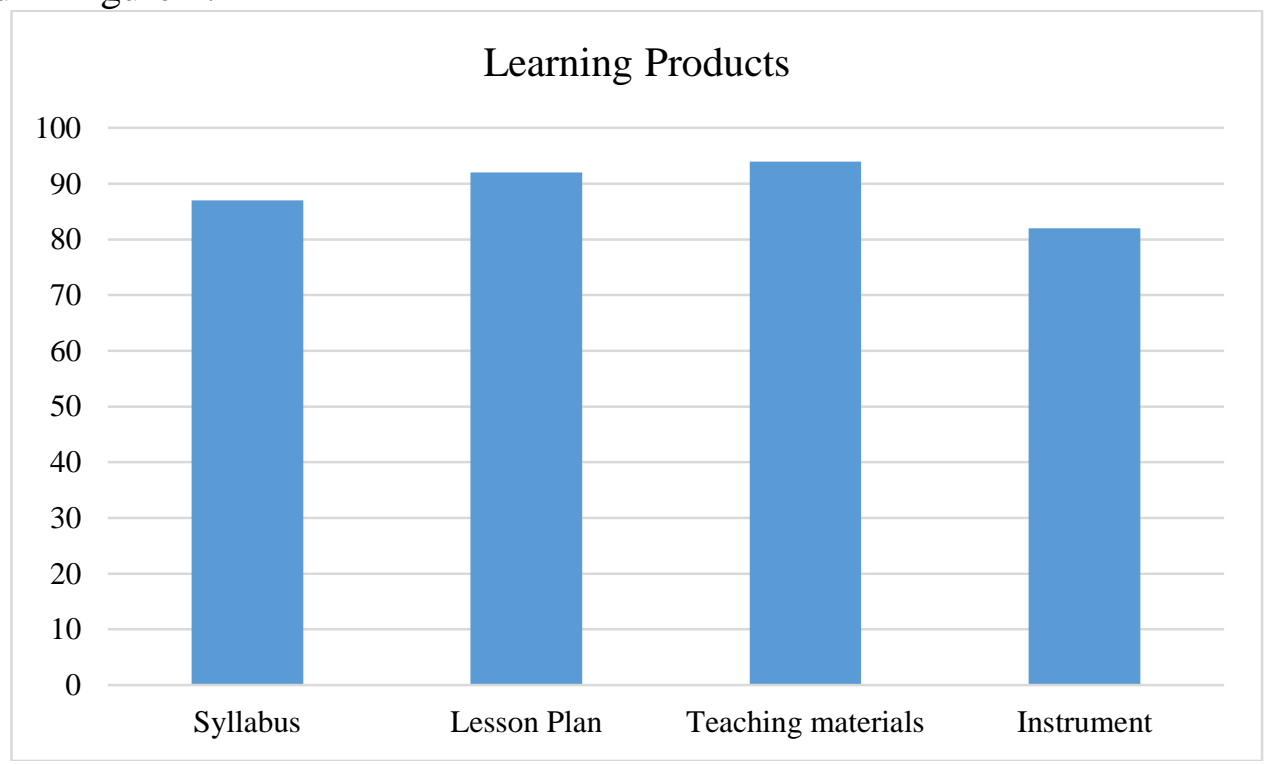

Figure 2. The results of the validation of learning products.

Table 2 concludes that the validity value of each component of the learning product developed meets the valid and very valid categories because the average validity score is $88.75 \%$. The percentage of instrument validity is $82 \%$ in the very valid category. However, there are some suggestions to improve the developed instrument. Comments and suggestions from expert validators that need to be added information about the distribution of scientific literacy instrument indicators. The instruments that are arranged must also be adapted to the characteristics of the students. In addition to the achievement of the final capability and indicators formulated need to be adjusted to the agreed Indonesian National Qualifications Framework.

At this development stage to produce the final product of learning devices after going through revisions based on input from experts or educational practitioners and data from trial results. Experiments continue to be carried out in order to have high technical quality and obtain effective and consistent tools. The hallmark of teaching materials developed with teaching materials at school or from publishers is that the teaching materials developed have aspects of training students' scientific literacy.

Teachers are not understood as the only source of learning, but must be able to plan and create other learning resources so as to create a conducive learning environment (Nurhasnah and Sari, 2020). Teaching materials can bridge and even combine the experience and knowledge of students (Azmy, 2018). In this regard, the teaching materials used by teachers in teaching activities are teaching materials developed by the Science MGMP not from the school itself. The use of materials developed by the IPA MGMP is not bad, but it is appropriate for teachers at the school to develop their own teaching materials used. This is 
based on the fact that the teacher knows how the situation (learning environment and learning method) of students is (Permatasari, et al., 2019; Ramdani, et al., 2020a).

One of the first stages after the product has been developed and is included in the core which is quite important in the development step is the validator validation stage. The purpose of validation on teaching materials that have been developed is in addition to producing a valid and valid product as well as to find out the shortcomings and weaknesses of the product developed based on suggestions and criticisms from the validators so that the final product is suitable for use by students widely.

In line with Gultom's research, (2017) states that the validation test aims to produce teaching materials that have standards and are suitable for use. Based on the results of the validation by the validator, the teaching materials developed were categorized as feasible and very feasible. The scores or scores given by the three validators on the teaching materials developed are feasible and valid, meaning that they can be used in the science learning process with the subject matter of the circulatory system and has referred to the 2013 curriculum. In accordance with the eligibility criteria, it can be continued to the school where the study is located.

In line with the research of Gultom (2017), Farda and Suryadinata (2017) and Amin (2016) stated that the teaching materials developed were eligible for validator criteria to be used in the learning process. Although teaching materials have been developed to obtain appropriate criteria, these teaching materials must be refined based on the suggestions and responses of the validator so that in their presentation they can be presented in full and supported by an attractive appearance so that students are interested in reading them. After the validation process of teaching materials by the validator has been completed and the criteria are suitable for use, a trial is carried out to determine the practicality and effectiveness of teaching materials.

\section{CONCLUSION}

Guided inquiry-based science teaching materials developed obtained valid results after going through a testing process by expert validators. Criticisms and suggestions from validators are used as material for device improvements. In addition, the content in science teaching materials was developed following the Dick and Carey development procedure. Furthermore, guided inquiry-based teaching materials are suitable for use in science learning, especially in the circulatory system material

\section{RECOMMENDATION}

Science teaching materials produced can be an alternative learning model applied by teachers in teaching science subjects, especially biology.

\section{ACKNOWLEDGMENT}

This research received no specific grant from any funding agency in the public,commercial, or not-for-profit sectors.

\section{REFERENCES}

Adisendjaja, Y. H. (2008). Analisis buku ajar biologi sma kelas $x$ di kota bandung berdasarkan literasi sains. Bandung: Jurusan Pendidikan Biologi, FMIPA Universitas Pendidikan Indonesia.

Amin, A. K. (2016). Analisis Bahan Ajar Modul Statistika Pada Program Studi Pendidikan Matematika IKIP PGRI Bojonegoro. Jurnal Pendidikan Edutama, 3(2), 1-8.

Ariningsih, I., Nawawi, E., \& Hartono, H. (2014). Pengembangan Panduan Praktikum Kimia Berbasis Inkuiri Terstruktur Di Kelas Xii Sman 1 Indralaya Utara. Jurnal Penelitian Pendidikan Kimia, 1(2), 147-155. 
Azmy, M. K., Purwoko, A. A., \& Hadisaputra, S. (2018). Development of teaching materials based on problem-based learning (PBL) to improve student learning outcomes. Proceedings Book.

Dick, W., Carey, L., Carey, J.O. (2011). The Systematic Design of Instruction. United State of America: P.A. Hutchison Company.

Fakhriyah, F., Masfuah, S., Roysa, M., Rusilowati, A., \& Rahayu, E. S. (2017). Student's Science Literacy in the Aspect of Content Science?. Jurnal Pendidikan IPA Indonesia, 6(1), 122870.

Farida, N., \& Suryadinata, N. (2017). Pengembangan Bahan Ajar Mata Kuliah Aljabar Linear Berbasis Open Ended. AKSIOMA: Jurnal Program Studi Pendidikan Matematika, 5(2), 145-151.

Fitriani, W., \& Lestari, I. (2014). Deskripsi Literasi Sains Siswa Dalam Model Inkuiri Pada Materi Laju Reaksi Di Sman 9 Pontianak. Jurnal Pendidikan dan Pembelajaran Khatulistiwa, 3(1).

Gultom, E. (2017). Pengembangan Bahan Ajar Inovatif Melalui Pendekatan Saintifik pada Pengajaran Termokimia. Jurnal Kimia Saintek Dan Pendidikan, 1(1), 22-29.

Hadisaputra, S., Gunawan, G., \& Yustiqvar, M. (2019). Effects of Green Chemistry Based Interactive Multimedia on the Students' Learning Outcomesand Scientific Literacy. Journal of Advanced Research in Dynamical and Control Systems, 11(7), 664-674.

Hasanah, J., Jamaludin, J., \& Prayitno, G. H. (2019). Bahan Ajar IPA Berbasis Inkuiri Terstruktur Untuk Meningkatkan Literasi Sains Peserta Didik SMP. Jurnal Pijar MIPA, 14(2), 18-24.

Jufrida, J., Basuki, F. R., Kurniawan, W., Pangestu, M. D., \& Fitaloka, O. (2019). Scientific Literacy and Science Learning Achievement at Junior High School. International Journal of Evaluation and Research in Education, 8(4), 630-636.

Komalasari, B. S., Jufri, A. W., \& Santoso, D. (2019). Pengembangan Bahan Ajar IPA Berbasis Inkuiri Terbimbing untuk Meningkatkan Literasi Sains. Jurnal Penelitian Pendidikan IPA, 5(2), 219-227.

Nieveen, N. (1999). Prototyping to reach product quality. In Design approaches and tools in education and training (pp. 125-135). Springer, Dordrecht.

Nurhasnah, N., \& Sari, L. A. (2020). E-Modul Fisika Berbasis Contextual Teaching and Learning Menggunakan Aplikasi Kvisoft Flipbook Maker Untuk Meningkatkan Literasi Sains Peserta Didik SMA/MA Kelas XI. Natural Science: Jurnal Penelitian Bidang IPA dan Pendidikan IPA, 6(1), 29-40.

Permatasari, I., Ramdani, A., \& Syukur, A. (2019). Pengembangan Bahan Ajar IPA Berbasis Inkuiri Terintegrasi Sets (Science, Environment, Technology And Society) pada Materi Sistem Reproduksi Manusia. Jurnal Pijar Mipa, 14(2), 74-78.

Pursitasari, I. D., Suhardi, E., Ardianto, D., \& Arif, A. (2019). Pengembangan bahan ajar bermuatan konteks kelautan untuk meningkatkan literasi sains siswa. Jurnal IPA \& Pembelajaran IPA, 3(2), 88-105.

Putra, M. I. S., Widodo, W., \& Jatmiko, B. (2016). The development of guided inquiry science learning materials to improve science literacy skill of prospective mi teachers. Jurnal Pendidikan IPA Indonesia, 5(1), 83-93.

Ramdani, A., Jufri, A. W., \& Jamaluddin, J. (2020a). Pengembangan Media Pembelajaran Berbasis Android pada Masa Pandemi Covid-19 untuk Meningkatkan Literasi Sains Peserta Didik. Jurnal Kependidikan: Jurnal Hasil Penelitian dan Kajian Kepustakaan di Bidang Pendidikan, Pengajaran dan Pembelajaran, 6(3), 433440.

Ramdani, A., Syukur, A., Gunawan, G., Permatasari, I., \& Yustiqvar, M. (2020b). Increasing Students' Metacognition Awareness: Learning Studies Using Science Teaching 
Materials Based on SETS Integrated Inquiry. International Journal of Advanced Science and Technology, 29(5), 6708-6721.

Sağlam, M. K., \& Şahin, M. (2017). Inquiry-based professional development practices for science teachers. Journal of Turkish Science Education, 14(4), 66-76.

Setiawan, A. R. (2019). Efektivitas pembelajaran biologi berorientasi literasi saintifik. Thabiea: Journal of Natural Science Teaching, 2(2), 83-94.

Suranti, N. M. Y., Gunawan, G., Harjono, A., \& Ramdani, A. (2020). The Validation of Learning Management System in Mechanics Instruction for Prospective Physics Teachers. Jurnal Pendidikan Fisika dan Teknologi, 6(1), 99-106.

Toharudin, U., Hendrawati, S., \& Rustaman, A. (2011). Membangun literasi sains peserta didik. Bandung: Humaniora. 